\title{
Hepatogenous Photosensitization in Steer by Brachiaria decumbens
}

\author{
Jéssica dos Santos Guimarães Carmo ${ }^{1}$, Joselito Nunes Costa ${ }^{1}$, Carmo Emanuel Almeida Biscarde ${ }^{2}$, \\ Luciano da Anunciação Pimentel', José Carlos de Oliveira Filho $\oplus^{1}$ \& Ana Paula Abreu Mendonça ${ }^{3}$
}

\begin{abstract}
Background: Although the etiology of hepatogenous photosensitization has not yet been fully elucidated, it is known that hepatotoxic substances (saponins) present in grasses of the genus Brachiaria spp. are responsible for intoxication of ruminants and horses, causing great economic losses in the whole world. Since this grass is the source of food for the herd in Brazil, and other countries of the world, the aim of this paper is to describe the epidemiological, clinical, laboratory and anatomopathological aspects of a steer with this disease.

Case: A 3-year-old Nellore steer was referred to veterinary care at a property in Bahia, with a 3-week history of swelling, loss of cutaneous tissue in the ear and scrotum region, and dry faeces. The animal was raised in pasture with Brachiaria decumbens along with five animals of different age and sex; however, it was the only one to present symptoms. Although the animal had been treated at the farm, there was no clinical improvement. On clinical examination, the steer was apathetic with jaundiced mucous membranes, nasal and ocular discharge, epiphora, and ulcers on the labial and gum commissure. The steer had leukocytosis with neutrophilia, anemia, and hyperfibrinogemia. The body condition score (BCS) was 2 (BCS ranges from 1 to 5), and the skin lesions observed were bedsores, necrosis and scabs in several regions. The increase in liver enzymes (GGT, AST) indicated hepatic impairment, suggesting a case of hepatogenous photosensitization. The therapeutic protocol instituted was enteral hydration, electrolyte replacement, topical application of ointment in the injured areas. In addition, it was recommended to maintain the animal in the shade, supply of good quality grass, and a new clinical evaluation in seven days. On new examination, it was observed that there was no satisfactory clinical improvement of the animal, and persistence of laboratory changes. Despite the poor prognosis, treatment was continued for another month with the same recommendations. However, in view of the severe clinical condition and unfavorable prognosis, the animal was submitted euthanasia. Necropsy revealed extensive areas of bedsores, erythema, severe jaundice in the mucous membranes, eyeballs and opaque corneas. The liver had an enlarged volume with bulging edges and a greenish color. The kidneys had a pale brownish color, with an irregular and mottled subcapsular surface, with blackened and depressed spots. Histologically, the cytoplasm of the hepatocytes was finely vacuolated, sometimes refringent and with an abundant presence of bile pigment. It was also observed in the middle of the liver parenchyma, multiple foci of accumulation of macrophages filled with vacuoles of different sizes containing saponins and crystals of saponins inside bile ducts. Furthermore, it was possible to observe hypertrophy and hyperplasia of Kupffer cells, disarrangement of hepatocytes with individual necrosis of hepatocytes.

Discussion: The diagnosis of hepatogenous photosensitization was based on history, clinical, laboratory and anatomopathological findings. Serum biochemistry was important to measure hepatic impairment and possible secondary lesions, which were confirmed by the necropsy. Although hepatogenous photosensitization is less common in adult cattle, it must be considered in the differential diagnosis of skin lesions, reduced appetite, and jaundice. Since it was a sporadic case, individual predisposition is probably a preponderant factor.
\end{abstract}

Keywords: cattle, photodermatitis, intoxication, liver injury, skin lesions. 


\section{INTRODUCTION}

Hepatogenous photosensitization occurs when substances present in plants or microorganisms alter the liver structure enough to impaired the process of excretion of phylloerythrin, photodynamic pigment formed from the catabolism of alimentary chlorophyll [22]. The non-eliminated phylloerythrin accumulates in the systemic circulation and, under the action of sunlight it absorbs certain wavelengths of ultraviolet rays and becomes active [29]. Activated, its molecules react with oxygen causing free radicals with cytotoxic action [15] that can result cellular lesions, intense inflammatory response, and eventually death [21,29].

The main clinical signs observed are: apathy, anorexia, edema, itch, keratitis, scabs in large extensions of skin, dehydration, and jaundiced [11,31]. In some cases, there may be neurological impairment attributed to secondary hepatic encephalopathy $[1,6,31]$.

Most of the cases report describes animals in pastures of Brachiaria decumbens [17,20,31]. The intoxication by Brachiaria spp. it's described under natural conditions in sheep [5], goats [25,30], cattle [17], buffaloes [19], and horses [2]. Although the disease by ingestion of this grass is frequent in Brazil, the epidemiological factors for its onset have not yet fully elucidated [17].

Once this disease causes economic damage in Brazil and in other countries [17], with an estimated annual loss of more than R $\$ 100,000.00$ [7], it's important to describe all findings for aid the clinical prevention of the emergence of new cases and minimizing the losses. Therefore, this paper describes epidemiological, clinical, laboratory, and anatomopathological aspects of hepatogenous photosensitization by Brachiaria decumbens in steer.

\section{CASE}

A 3-year-old Nellore steer was referred to veterinary care at a property in the city of Maragogipe, Bahia's Recôncavo region, with a 3-week history of swelling, loss of cutaneous tissue in the ear and scrotum region, and dry faeces. The animal was raised on pasture along with 5 animals of different age and sex; however, it was the only one to present symptoms. The diet offered was the same for the entire group of animals, consisting of commercial feed in the trough without mineral supplementation, and water ad libitum. According to the owner, the exchange of pastures occurred on a routine basis depending on the availability of forage and the number of animals. On the farm before veterinary care, the animal had been treated with fluid therapy with energetic and vitamin serum [Fortemil ${ }^{1}$ - $500 \mathrm{~mL}$ intravenous, single dose]; mineral supplementation of calcium, phosphorus and magnesium [Calfon ${ }^{2}$ - $200 \mathrm{~mL}$ intravenous, single dose]; liver protector [Mercepton ${ }^{3}-100 \mathrm{~mL}$, intravenous, single dose], enema with sodium phosphate solution [Phosfoenema ${ }^{4}$ - $130 \mathrm{~mL}$, intra-rectal, single dose], and antibiotic therapy with penicillin [Agrothal ${ }^{5}$ ] and tetracycline $\left[\right.$ Terramicina $\left.{ }^{6}\right]$. However, there was no clinical improvement.

On examination, the steer was apathetic with jaundiced mucous membranes, nasal and ocular discharge, epiphora, and ulcers on the labial and gum commissure. The body condition score (BCS) was 2 [BCS ranges from 1 to 5]. The skin lesions observed were bedsores, necrosis and crusting in muffle regions, the ventral surface and the tip of the tongue, the inner surface of the ears, the dewlap, the ventral portion of the thorax and abdomen (Figure 1). With the exception of the dry, smelly-faeces revealed by examination of rectal palpation, changes in other systems were not evidenced.

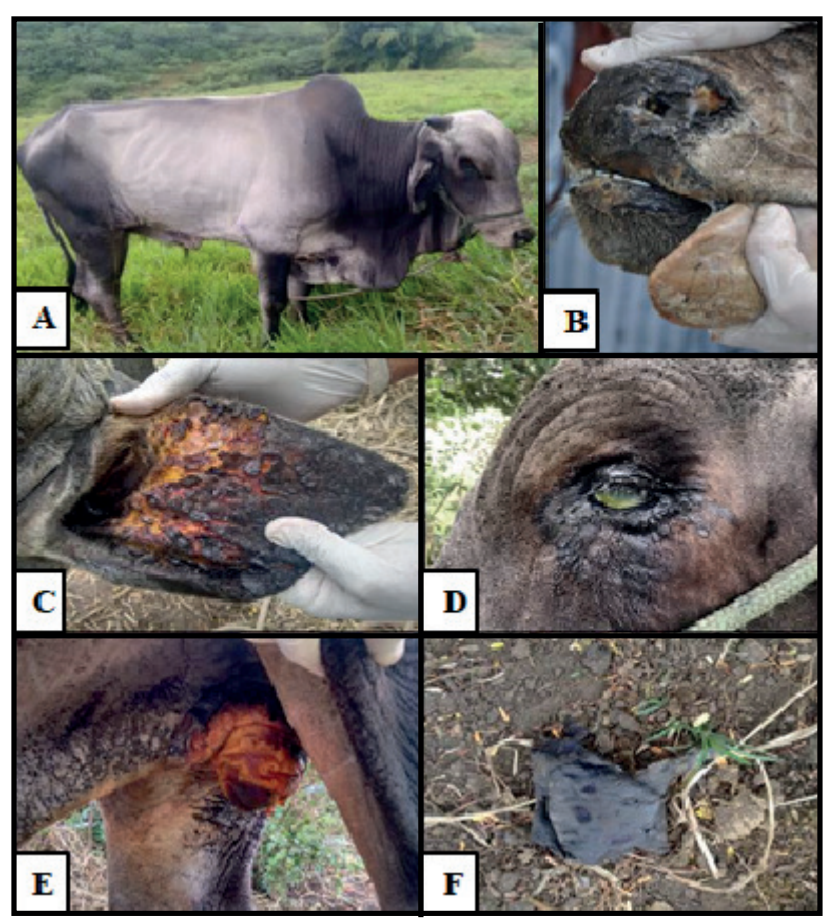

Figure 1. A- Steer with hepatogenous photosensitization caused by ingestion of Brachiaria decumbens and some observed changes. B- Ulcerative lesion on the tongue, flaking in the muffle and nasal discharge. C- Appearance of tree bark on the inner side of the ear. D- Epiphora and yellowish cornea. E \& F- Loss of skin tissue in testis. 
Blood samples were collected by jugular venipuncture in Vacutainer siliconized tubes containing $10 \%$ EDTA (Vacuette ${ }^{7}$ ) for measurements of blood count, total plasma protein (TPP), plasma fibrinogen, and serum biochemistry [8]. The complete blood count revealed anemia, hyperfibrinogenemia; leukocytosis with neutrophilia; increased gamma glutamyl transferase, aspartate aminotransferase, urea, total, direct and indirect bilirubin. The animal also presented the presence of crystals of bilirubin, urobilinogen and bilirubin in urinalysis.

The diagnostic was of hepatogenic photosensitization, and the therapeutic protocol was enteral hydration, electrolyte replacement, topical application of ointment composed of urea, dihydrostreptomycin and penicillin $\left[\mathrm{Ganadol}^{8}\right]$ in the injured areas. In addition, it was recommended to keep the animal in the shade in order to avoid exposure to sunlight, supply of good quality grass in the trough and a new clinical evaluation in seven days.

On new examination, it was observed that there was no suitable clinical improvement of the animal, and persistence of the findings in new laboratory tests. Despite the poor prognosis, treatment was continued for another month with the same recommendations. However, in view of the severe clinical condition and unfavorable prognosis, the animal was submitted euthanasia.

Necropsy revealed edema of the dewlap, extensive areas of bedsores. On the skin, dry areas with cracks, erythema, erosions and severe ulcers associated with crusts were observed, mainly on the ears, limbs, face, lip and scrotum. In addition, severe jaundice in the mucous membranes, eyeballs, opaque corneas, and Haemonchus placei in the abomasum. The liver had an enlarged volume with bulging edges and a greenish color. The kidneys had a pale brownish color, with an irregular and mottled subcapsular surface, with blackened and depressed spots, which extended through the parenchyma until the corticomedullary transition. Fragments of the liver, kidney, and lymph nodes were collected, fixed in 10\% formaldehyde, and routinely processed and stained with hematoxylin and eosin $\left(\mathrm{HE}^{9}\right)$ for histopathological evaluation.

The microscopic examination showed extensive areas of proliferation of fibrous connective tissue in the liver, predominantly in the periportal space, giving the appearance of bridging fibrosis, associated with the proliferation of bile ducts (Figure 2A). The cytoplasm of the hepatocytes was finely vacuolated, sometimes refringent and with an abundant presence of bile pigment (Figure 2B). It was also observed in the middle of the liver parenchyma, multiple foci of accumulation of macrophages filled with vacuoles of different sizes (consistent with saponins), and crystals of saponins inside bile ducts. Furthermore, it was possible to observe hypertrophy and hyperplasia of Kupffer cells, disarrangement of hepatocytes with individual necrosis of hepatocytes. In the hepatic lymph node, evident lymphoid rarefaction and macrophages full of bile pigment were observed. In the kidney, it was possible to observe proliferation of mesangial cells, thickening of the basement membrane of mesangial capillaries, dilation of the urinary space, multiple foci of lymphoplasmacytic interstitial nephritis, tubular ectasia sometimes associated with hyaline cylinder

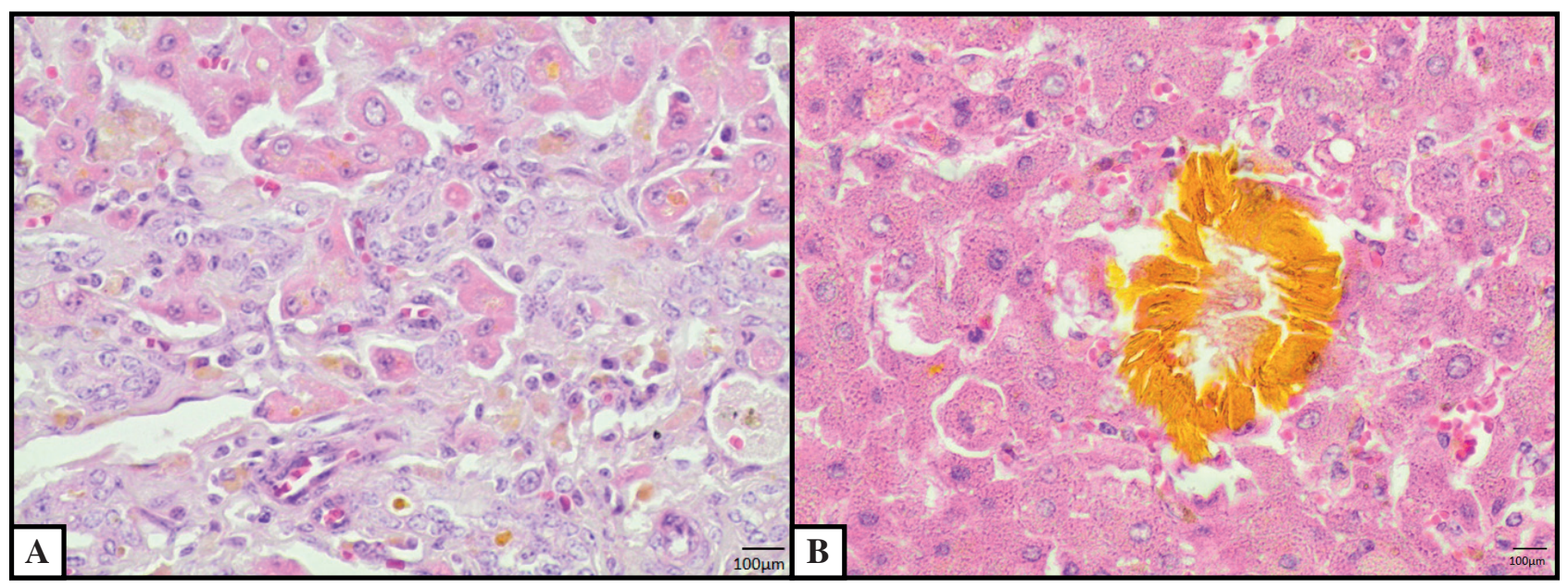

Figure 2. Histopathological examination of a steer's liver with hepatogenous photosensitization. A- Fibrosis and extra hepatocyte crystals [HE; Obj.100x] B- Crystals of saponin and bile pigment found within hepatocyte cytoplasm [HE; Obj.100x]. 
and bile pigment, which was also observed adhered to cells tubular.

Based on epidemiological data and clinical signs, hepatogenous photosensitization was diagnosed. The complementary exams, especially necropsy and histopathology, were performed as diagnostic confirmation methods.

\section{DISCUSSION}

In bovines, hepatogenous photosensitization must be differentiated from other diseases with jaundice, bilirubinemia and hemoglobinuria, especially babesiosis, dermatopathies such as scabies, solar dermatitis, and dermatophytosis in calves, that differ by the aspect of distribution of the lesions that are not restricted to portions of depigmented skin $[2,22]$.

Although photosensitization is more common in younger animals, especially during weaning, a period of high stress for animals [23], the present paper reports the condition in an adult bovine similar to other cases available in the literature [26]. The steer was the only one affected in a group of five animals sustained under the same management, conditions similar to those of other producers in the region. Since it was a sporadic case, individual predisposition is probably a preponderant factor. It should be emphasized that Brachiaria decumbens present on picket is correlated with higher concentrations of saponins, higher toxicity, and greater potential for intoxication [31]. In addition, the concentration of saponins can vary in the same species, according to the planting location, plant age, stage of development and environmental stress $[12,18]$. Thus, as the picket was not grazed for some time, it is likely that the site had higher concentrations of saponins, as suggested by some studies [23].

The onset of skin lesions occurred shortly after the exchange of pasture with clinical signs consistent with the photosensitization outbreaks described $[13,17,26,28]$. Although the loss of skin tissue in the testis has not been reported in previous cases, the lesions observed are similar to those described in the udder [22]. The anemic syndrome in cattle with clinical presentation of the disease is described [4], however, it cannot be said that the anemia observed in the steer in the present case is due to this syndrome or due to blood loss by Haemonchus placei observed at necropsy [16].

Leukocytosis with neutrophilia and hyperfibrinogenemia are sensitive parameters in cattle that indicate an active inflammatory and/or infectious process. Skin lesions had secondary bacterial infection and purulent secretion, processes that can justify these parameters, as well as internal lesions described in kidneys and liver caused by the direct or indirect action of saponins as described in the literature $[13,16]$.

Similar to a previous study [3], high concentrations of the AST and GGT enzymes were observed in the present clinical case, suggesting injury in hepatobiliary system consistent with the disease, demonstrating that the serum biochemistry is sensitive for the diagnosis of hepatogenous photosensitization. Furthermore, the steer had a high concentration of creatine phosphokinase (1896 IU/L), probably due to the animal's preferential recumbence [14]. The increased values of total bilirubin and its fractions suggest that pre-hepatic and hepatic jaundice, due to the effect of saponins on the bilirubin conjugation mechanism and bile duct obstruction $[9,27]$. The increased value of urea is probably due to starvation that causes body protein stores to deplete [9]. The presence of urobilinogen, free bilirubin and crystals observed in urinalysis are consistent with cases of hepatobiliary diseases with cholestasis [9].

The prognosis in this case report was considered reserved, since the animal had intense and chronic injuries in the first clinical examination, without response to the treatment instituted. The worsening of lesions was a decisive factor for the euthanasia.

The necropsy findings were compatible with the clinical and laboratory changes observed in the present animal and in previous cases [24,31,32]. Histopathology characterized the action of saponins as an etiological agent of the disease. The accumulation of bile pigment and birefringent crystals, in addition to foamy cytoplasm macrophages, present in the liver, bile ducts and lymph nodes, and individual hepatocyte necrosis, were important findings for confirmation of the histopathological diagnosis $[10,31,32]$.

It's important to point out that although the other herd animals in the herd have not been clinically affected, could have significant liver changes that would result in the liver being condemned in the slaughter future. Since it is possible that cattle after liver damage have stopped the consumption of toxic principles [7].

Despite being less common, adult cattle are susceptible to the development of photosensitization by Brachiaria spp. In addition to a good knowledge of the epidemiological aspects that predispose the disease, it's essential to perform a good clinical examination to 
determine the causes of disease. The serum biochemistry is efficient to evaluate hepatic impairment and possible secondary lesions, while the anatomopathological features are conclusive for the diagnosis of disease. Therefore, hepatogenous photosensitization should be considered in the differential diagnosis of adult cattle with skin lesions, appetite reduction, and jaundice.

\section{MANUFACTURERS}

'Ouro Fino Saúde Animal Ltda. Cravinhos, SP, Brazil.

${ }^{2}$ Bayer S.A. São Paulo, SP, Brazil.

${ }^{3}$ Laboratório Bravet Ltda. Rio de Janeiro, RJ, Brazil.
${ }^{4}$ Cristália Produtos Químicos Farmacêuticos Ltda. São Paulo, SP, Brazil.

${ }^{5}$ Fabiani Saúde Animal Ltda. São Paulo, SP, Brazil.

${ }^{6}$ Laboratórios Pfizer Ltda. São Paulo, SP, Brazil.

${ }^{7}$ Greiner Bio-One Produtos Médicos Hospitalares Ltda. Americana, SP, Brazil.

${ }^{8}$ Zoetis Indústria de Produtos Veterinários Ltda. São Paulo, SP, Brazil. ${ }^{9}$ Laboratório de Patologia Veterinária, Hospital Universitário de Medicina Veterinária, Universidade Federal Recôncavo da Bahia. Cruz das Almas, BA, Brazil.

Declaration of interest. The authors report no conflicts of interest. The authors alone are responsible for the content and writing of the paper.

\section{REFERENCES}

1 Albernaz T.T., Silveira J.A.S., Silva N.S., Oliveira H.S., Reis A.S.B., Oliveira, C.M.C., Duarte M.D. \& Barbosa J.D. 2010. Fotossensibilização em ovinos associada à ingestão de Brachiaria brizantha no estado do Pará. Pesquisa Veterinária Brasileira. 30(9): 741-748.

2 Barbosa J.D., Oliveira C.M.C., Tokarnia C.H. \& Peixoto P.V. 2006. Fotossensibilização hepatógena em equinos pela ingestão de Brachiaria humidicola (Gramineae) no Estado do Pará. Pesquisa Veterinária Brasileira. 26(3): 147-153.

3 Cardona-Álvarez J., Vargas-Vilória M. \& Paredes-Herbach E. 2015. Estudio clínico e histopatológico de la dermatitis fototóxica en terneros Cebú en pastoreo de Brachiaria decumbens. Revista MVZ Córdoba. 21(2): 5366-5380.

4 Connor H.E. 1977. Poisonous Plants in New Zealand. 2nd edn. Wellington: Keating Government Printer, pp.64-70.

5 Costa S.Z.R., Nespoli P.B., Bezerra Júnior P.S., Nogueira V.A., Driemeier D., Boabaid F.M., Peixoto P.V., Armién A.M. \& França T.N. 2013. Avaliação lectino-histoquímica de fígado e rim de ovinos com fotossensibilização causada por Brachiaria decumbens. Pesquisa Veterinária Brasileira. 33(8): 955-962.

6 Cruz C., Driemeier D., Pires V.S. \& Schenkel E.P. 2001. Experimentally induced cholangiohepatopathy by dosing sheep with fractionated extracts from Brachiaria decumbens. Journal of Veterinary Diagnostic Investigation. 13(2): 170-172.

7 Faccin T.C., Brumatti R.C., Lima S.C., Madureira R.C., Fernandes C.E.S., Kommers G.D. \& Lemos R.A.A. 2015. Perdas econômicas pela condenação em matadouro frigorífico de fígados de bovino por fibrose causada por ingestão de Braquiaria spp. Pesquisa Veterinária Brasileira. 35(6): 547-551.

8 Jain N.C. 1993. Essentials of Veterinary Hematology. Philadelphia: Lea \& Febiger, pp.66-67.

9 Kerr M.G. 2003. Exames Laboratoriais em Medicina Veterinária: Bioquímica Clínica e Hematologia Veterinária. 2.ed. São Paulo: Roca, pp.119-130.

10 Lemos R.A.A. \& Purisco E. 2002. Plantas Que Causam Fotossensibilização Hepatógena. In: Lemos R.A.A., Barros N. \& Brum K.B. (Eds). Enfermidades de Interesse Econômico em Bovinos de Corte: Perguntas e Respostas. Campo Grande: Editora UFMS, pp.147-155.

11 Lemos R.A.A., Ferreira L.C.L., Silva S.M., Nakazato L. \& Salvador S.C. 1996. Fotossensibilização e colangiopatia associada a cristais em ovinos em pastagem com Brachiaria decumbens. Ciência Rural. 26(1): 109-113.

12 Lima F.G., Ribeiro C.S., Andrade D.D.F., Guimarães V.Y., Wysocki Júnior H.L., Haraguchi M. \& Fioravanti M.C.S. 2009. Braquiária: fatores que interferem nos níveis de saponina. Ciência Animal Brasileira. 1: 367-372.

13 Mendonça F.S., Camargo L.M., Freitas S.H., Dória R.G.S., Baratella-Evêncio L. \& Evêncio Neto J. 2008. Aspectos clínicos e patológicos de um surto de Fotossensibilização hepatógena em ovinos pela ingestão de Brachiaria decumbens (Gramineae) no município de Cuiabá, Mato Grosso. Ciência Animal Brasileira. 9(4): 1034-1041.

14 Meyer D.J., Coles H.E. \& Rich L.J. 1995. Medicina de Laboratório Veterinária: Interpretação e Diagnóstico. São Paulo: Roca, pp.3-6.

15 Moan J. \& Sommer S. 1985. Oxygen dependence of the photosensitizing effect of hematoporphyrin derivative in NHIK 3025 cells. Cancer Research. 45(4): 1608-1610.

16 Molento M.B., Tasca C., Gallo A., Ferreira M., Bononi E \& Stecca E. 2004. Método Famacha como parâmetro clínico individual de infecção por Haemonchus contortus em pequenos ruminantes. Ciência Rural. 34(4): 1139-1145. 
17 Moreira N., Martin C.C., Hilgert A.R., Tostes R.A. \& Viott A.M. 2018. Surto de fotossensibilização hepatógena em bovinos por ingestão de Brachiaria decumbens no município de Cascavel-PR. Archives of Veterinary Science. 23(1): 52-62.

18 Oleszek W.A. 2002. Chromatographic determination of plant saponins. Journal of Chromatography A. 967(1): 147162.

19 Oliveira C.H.S., Barbosa J.D., Oliveira C.M.C., Bastianetto E., Melo M.M., Haraguchic M., Freitas L.G.L., Silva M.X. \& Leite R.C. 2013. Hepatic photosensitization in buffaloes intoxicated by Brachiaria decumbens in Minas Gerais State, Brazil. Toxicon. 73: 121-129.

20 Pedroso P.M.O., Pinheiro E.E.G., Oliveira R.S. \& Macêdo J.T.S.A. 2018. Plantas tóxicas para animais de produção na Região do Recôncavo da Bahia. Revista Brasileira de Higiene e Sanidade Animal. 12(1): 120-132.

21 Quinn J., Kessell A. \& Weston L. 2014. Secondary Plant Products Causing Photosensitization in Grazing Herbivores: Their Structure, Activity and Regulation. International Journal of Molecular Sciences. 15(1): 1441-1465.

22 Radostits O.M., Gay C.C., Blood D.C. Hinchcliff K.W \& Peter D.C. 2007. Veterinary Medicine: A Textbook of the Diseases of Cattle, Horses, Sheep, Pigs and Goats. 10th edn. London: Saunders, pp.347-360.

23 Riet-Correa F. \& Méndez M.C. 2009. Intoxicações por Plantas e Micotoxinas. In: Riet-Correa F., Schild A.L., Lemos R.A.A. \& Borges J.R.J. (Eds). Doenças de Ruminantes e Eqüídeos. 3.ed. Santa Maria: Pallotti, pp.99-2019.

24 Riet-Correa F., Haraguchi M., Dantas A.F.M., Burakovas R.G., Yokosuka A., Mimaki Y., Medeiros R.M.T. \& Matos P.F. 2009. Sheep poisoning by Panicum dichotomiflorum in northeastern Brazil. Pesquisa Veterinária Brasileira. 29(1): 94-98.

25 Rosa F.B., Rubin M.I.B., Martins T.B., Lemos R.A.A., Gomes D.C., Pupin R.C., Lima S.C. \& Barros C.S.L. 2016. Spontaneous poisoning by Brachiaria decumbens in goats. Pesquisa Veterinária Brasileira. 36(5): 389-396.

26 Sant'ana F.J.F., Reis Júnior J.L., Freitas Neto A.P., Moreira Júnior C.A., Vulcani V.A.S., Rabelo R.E. \& Terra J.P. 2014. Plantas tóxicas para ruminantes do Sudoeste de Goiás. Ciência Rural. 44(5): 875-881.

27 Santos J.A., Riet-Correa F., Simoes S.V.D. \& Barros C.S.L. 2008. Patogênese, sinais clínicos e patologia das doenças causadas por plantas hepatotóxicas em ruminantes e eqüinos no Brasil. Pesquisa Veterinária Brasileira. 28(1): 1-14.

28 Saturnino K.C., Mariani T.M., Barbosa-Ferreira M., Brum K.B., Fernandes C.E.S. \& Lemos R.A.A. 2010. Intoxicação experimental por Brachiaria decumbens em ovinos confinados. Pesquisa Veterinária Brasileira. 30(3): 195-202.

29 Scheie E., Flåøyen A., Moan J. \& Berg K. 2002. Phylloeritrin: Mechanisms for cellular uptake and location, photosensitization and spectroscopic evaluation. New Zealand Veterinary Journal. 50(3): 104-110.

30 Silveira J.A.S., Albernaz T.T., Silva N.S., Lopes C.T.A., Cerqueira V.D., Oliveira C.M.C. \& Duarte M.D. 2009. Fotossensibilização hepatógena em caprinos associada à ingestão de Brachiaria brizantha no estado do Pará. In: VIII Congresso Brasileiro de Buiatria (Belo Horizonte, Brazil). Ciência Animal Brasileira. 10(Suppl 1): 336-341.

31 Souza R.I.C., Riet-Correa F., Brum K.B., Fernandes C.E., Barbosa-Ferreira M. \& Lemos R.A.A. 2010. Intoxicação por Brachiaria spp. em bovinos no Mato Grosso do Sul. Pesquisa Veterinária Brasileira. 30(12): 1036-1042.

32 Tokarnia C.H., Brito M.F., Barbosa J.D., Peixoto P.V. \& Döbereiner J. 2012. Plantas Tóxicas do Brasil para Animais de Produção. 2.ed. Rio de Janeiro: Helianthus, pp.323-335. 